\title{
MODELS FOR ESTIMATING MACRONUTRIENTS IN Mimosa scabrella Bentham
}

\author{
Saulo Jorge Téo ${ }^{1}$, Sebastião do Amaral Machado ${ }^{2}$, Afonso Figueiredo Filho², Carlos Bruno Reissmann²
}

(received: February 6, 2009; accepted: April 30, 2010)

\begin{abstract}
The aim of this work was to adjust and test different statistical models for estimating macronutrient content in the above-ground biomass of bracatinga (Mimosa scabrella Bentham). The data were collected from 25 bracatinga trees, all native to the north of the metropolitan region of Curitiba, Paraná state, Brazil. To determine the biomass and macronutrient content, the trees were separated into the compartments leaves, branches $<4 \mathrm{~cm}$, branches $\geq 4 \mathrm{~cm}$, wood and stem barks. Different statistical models were adjusted to estimate $\mathrm{N}, \mathrm{P}, \mathrm{K}, \mathrm{Ca}$ and $\mathrm{Mg}$ contents in the tree compartments, using dendrometric variables as the model independent variables. Based on the results, the equations developed for estimating macronutrient contents were, in general, satisfactory. The most accurate estimates were obtained for the stem biomass compartments and the sum of the biomass compartments. In some cases, the equations had a better performance when crown and stem dimensions, age and dominant height were included as independent variables.
\end{abstract}

Key words: Bracatinga, nutrient contents, forest biomass.

\section{MODELAGEM PARA ESTIMATIVA DE MACRONUTRIENTES EM Mimosa scabrella Bentham}

RESUMO: Neste trabalho, objetivou-se ajustar e testar diversos modelos estatísticos para estimativa do conteúdo de macronutrientes da biomassa aérea de bracatinga (Mimosa scabrella Bentham). Os dados desta pesquisa provieram de 25 árvores de bracatingais nativos da porção norte da região metropolitana de Curitiba, no estado do Paraná. As árvores foram separadas nos compartimentos folhas, galhos $<4 \mathrm{~cm}$, galhos $\geq 4 \mathrm{~cm}$, madeira e casca do fuste, para a determinação da biomassa e macronutrientes. Diversos modelos estatísticos foram ajustados, visando a estimar os conteúdos de $\mathrm{N}, \mathrm{P}, \mathrm{K}$, Ca e Mg para os diferentes compartimentos da árvore, utilizando variáveis dendrométricas como variáveis independentes dos modelos. Conforme os resultados encontrados, é possível afirmar que as equações desenvolvidas para a estimativa do conteúdo de macronutrientes foram, de maneira geral, satisfatórias. As equações estimam melhor os macronutrientes para os compartimentos da biomassa do fuste e para os compartimentos da biomassa somados. Em alguns casos, foram observadas melhoras no desempenho das equações quando dimensões da copa, do fuste, idade e altura dominante foram inseridas como variáveis independentes.

Palavras-chave: Bracatinga, conteúdo de nutrientes, biomassa florestal.

\section{INTRODUCTION}

One of the most important components of plant nutrition is nutrient cycling, that is, the replacements and losses of nutrients in an ecosystem due to different natural processes, as well as to human intervention. In forest ecosystems, wood harvesting is among those activities that contribute most to nutrient exportation.

In forests managed in long rotations with utilization of only the tree stem, the amount of nutrients removed in their exploitation is lower that the nutrient concentration in the soils and in the different nutrient entrance mechanisms (KIMMINS, 1977). However, due to the oil crisis, large scale uses of the forest biomass, as a source of energy and other products, have been proposed since the 1970's (YOUNG, 1968). Also, genetic breeding has enhanced forest yield and, consequently, decreased rotation age.
As the uses of the different forest biomass compartments were intensified, there was also a growing concern with the effects of nutrient losses in these compartments, such as leaves, branches and roots, apart from the nutrient losses caused by exploitation of the tree stems, as was already occurring.

The bracatinga forests in the metropolitan region of Curitiba, Paraná state, Brazil, are managed in a traditional system, due to the experience of the small scale producers in the area. This system involves fire induced natural regeneration (burning practices), planting of annual crops in the first year, thinning of the vegetation along with harvesting of the annual crops, development of the bracatinga forest for 7 years and clear cutting. This cycle is repeated every 7 years.

Baggio \& Carpanezzi (1997) highlight that traditional methods of bracatinga (Mimosa scabrella Bentham)

${ }^{1}$ Forest Engineer, M. Sc. in Forest Engineering, Lecturer at the Forest Engineering course at Universidade do Oeste de Santa Catarina/ UNOESC -Campus Xanxerê - Rua Dirceu Giordani, 696 - Jardim Universitário - 89820-000 - Xanxerê, SC - sauloteo@yahoo.com.br ${ }^{2}$ Forest Engineer, $\mathrm{PhD}$ in Forest Engineering, Senior Lecturer of the Forest Engineering course at the Universidade Federal do Paraná/ UFPR - Av. Prefeito Lothário Meissner, 632 - Jardim Botânico - 80210-170 - Curitiba, PR - samachado@ufpr.br, reissman@ufpr.br, afig@ufpr.br

Cerne, Lavras, v. 16, n. 3, p. 323-334, jul./set. 2010 
management cause a high nutrient exportation. Also, in most cases, the number of rotations on the same terrain is high and reposition fertilization is not done, leading to lower yields. Due to all of these factors, a thorough knowledge of the nutrients in bracatinga forests, and also of their different flows and transformations, is important.

From the nutrients accumulated in the wood and other biomass compartments, it is possible to determine the amount of nutrients potentially exported through of firewood exploitation, as well as the nutrients in leaves and branches that are affected by fire, providing a guideline for their replacement.

Macronutrient contents estimated in function of easily obtained variables, through statistical models, may be a useful and accurate tool for determining nutrient balance in bracatinga forests and their nutritional requirements.

According to Lear et al. (1984), when the nutrient concentration is multiplied by the biomass and estimated in function of the diameter, the relation is strong due to the excellent relation between biomass and diameter. Nutrient concentration can be estimated both by a nutrient estimative regression equation in a specific location or by multiplication of the mean biomass of the tree compartments by the mean nutrient concentration. Among the studies dedicated to developing equations for estimating nutrient contents in different regions are Bellote et al. (1983), Laclau et al. (2000), Lear et al. (1984), Hoppe (2003), Moro et al. (2007), Ranger et al. (1995) and Ranger \& Gelhaye (2001).

The aim of this work was to adjust and test different statistical models for estimating the total macronutrient content and the nutrient contents in the different tree above-ground biomass compartments using dendrometric variables.

\section{MATERIAL AND METHODS}

The study area was the northern portion of the metropolitan region of Curitiba, Paraná state, specifically the municipalities of Almirante Tamandaré, Campina Grande do Sul, Campo Magro and Colombo (Figure 1). The mean altitude in the area is $950 \mathrm{~m}$. The climate, in the Köeppen classification, is $\mathrm{Cfb}$, with a mean annual temperature of $16,5^{\circ} \mathrm{C}$ and annual rainfall of approximately $1500 \mathrm{~mm}$ (MAACK, 2002).

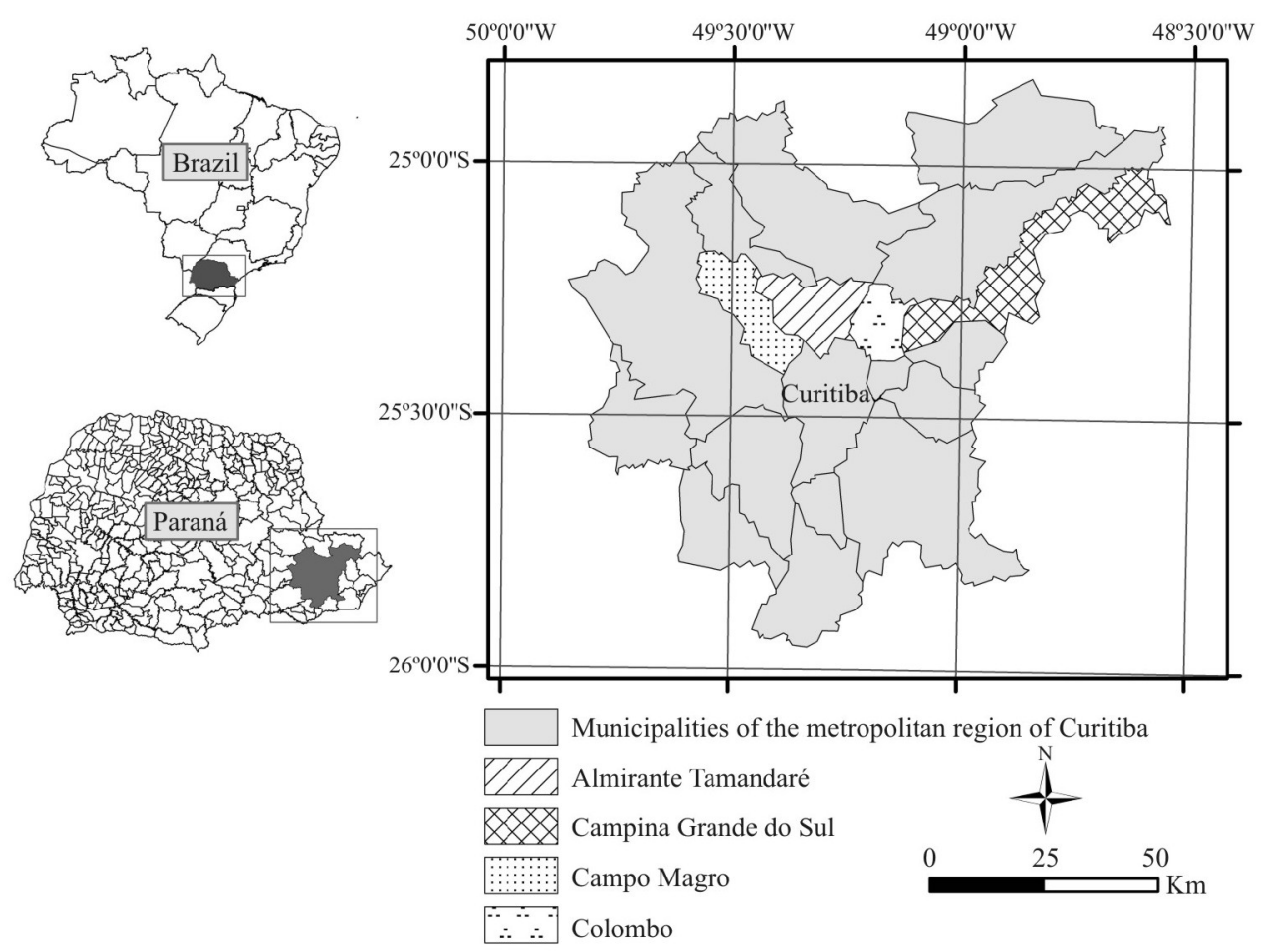

Figure 1 - Map of the metropolitan region of Curitiba and of the study area.

Figura 1 - Mapa da região metropolitana de Curitiba destacando a área de estudo.

Cerne, Lavras, v. 16, n. 3, p. 323-334, jul./set. 2010 
Most of the soils associated with bracatinga forests are classified as alic Cambisols with layers varying from deep to shallow, especially in strong undulated relief (ZILLER et al., 1996).

After extensive bibliographic review, Somarriba \& Kass (2001) affirm that bracatinga forest soils almost invariably present low fertility levels, with $6 \%$ to $8 \%$ of organic matter $(0-20 \mathrm{~cm}), \mathrm{pH}$ values frequently below 4 , phosphate levels below $10 \mathrm{mg} \cdot \mathrm{kg}^{-1}$ and base sum below $1 \mathrm{cmol} \cdot \mathrm{cg}^{-1}$.

To obtain the experimental data 25 trees, distributed around the study area, were cut down between June and July 2007. Table 1 shows the diametric, height and age variations between the samples trees.

Table 1 - Diametric, height and age variations between the 25 sampled trees from bracatinga forests (Mimosa scabrella Bentham) native to the metropolitan region of Curitiba.

Tabela 1 - Variação diamétrica, de alturas e de idades das 25 árvores amostradas em bracatingais (Mimosa scabrella Bentham) nativos na região metropolitana de Curitiba.

\begin{tabular}{lccc}
\hline & Mean & Minimum & Maximum \\
\hline Diameter at breast height $(\mathrm{cm})$ & 11.2 & 7.0 & 20.0 \\
Total height $(\mathrm{m})$ & 14.3 & 10.2 & 19.5 \\
Age (years) & 9 & 6 & 14 \\
\hline
\end{tabular}

On the field, the diameter at breast height (d) and crown diameter $(\mathrm{dc})$ were measured before the trees were cut down. Total height and stem height were then measured and the trees were divided into the compartments: leaves, branches with less than $4 \mathrm{~cm}$ diameter, branches with $4 \mathrm{~cm}$ diameter or above, stem wood and stem bark. The green weight of each of the biomass compartments was determined on the field and a sample was taken for determining dry weight in the laboratory. Three samples consisting of $5 \mathrm{~cm}$ thick disks were taken from the tree stem. The samples of the larger and smaller branches presented green weight of, approximately, $500 \mathrm{~g}$. Lastly, leaf samples of approximately $150 \mathrm{~g}$ of green weight were made. To obtain the dry weight, later used in chemical analysis, the samples were dried at $65^{\circ} \mathrm{C}$ and ground in a knife mill with a 30 mesh sieve.

$\mathrm{N}, \mathrm{P}, \mathrm{K}, \mathrm{Ca}$ and $\mathrm{Mg}$ analyses were done at the Biogeochemical and Plant Nutrition Laboratory of the Soils Department, in the Agricultural Sciences Sector of the Federal University of Paraná. The dry matter analyzed was obtained through sulphuric digestion for $\mathrm{N}$ and dry digestion for the remaining nutrients. $\mathrm{N}$ concentration was determined by nitrogen distillation and titration of the samples in the Kjeldahl method. After dry digestion, $\mathrm{P}$ concentration was determined through colorimetry, $\mathrm{K}$ by a flame photometer and $\mathrm{Ca}$ and $\mathrm{Mg}$ concentrations were determined in an atomic absorption spectrophotometer.

After determining the dry weight and nutrient concentration of each of the biomass compartments, the nutrient content (in grams) could be estimated separately for each of the compartments (leaves, branches $<4 \mathrm{~cm}$, branches $\geq 4 \mathrm{~cm}$, wood and bark), and for the sum of the compartments: leaves + branches $<4 \mathrm{~cm}$, firewood (wood + bark + branches $\geq 4 \mathrm{~cm}$ ) and the whole above-ground biomass. In total, there are 5 macronutrients for each biomass compartment and their sums, resulting in 40 dependent variables to be estimated.

The modeling independent variables were: diameter at breast height (d), total height (h), stem height (hf), crown diameter (dc), crown height (hc), crown ratio (rc), dominant height $\left(\mathrm{h}_{\mathrm{dom}}\right)$ and age (I); and also their combinations and logarithm, totalizing 42 independent variables.

After determining all the variables, the first step was build a correlation matrix and apply the stepwise procedure, to obtain the best regression equation by insertion and elimination of independent variables, according to their correlation coefficients and statistical significance measured by the partial "F" values. In this work, the significance level for insertion and elimination of variables in the statistical model was $10 \%$.

Apart from the stepwise procedure, 15 other statistical models traditionally used in forests to estimate individual tree volume were adjusted and another 15 statistical models were modified, among which 10 were adjusted to estimate nutrient content in the crown and 5 in the stem compartments. The modified statistical models were built based on traditional models, in which canopy and stem dimensions were included as independent variables.

The best adjusted model was selected based on the adjusted determination coefficient $\left(\mathrm{R}^{2}\right.$ aj.), standard estimate error (syx\%) and graphic analysis of the residues in percentage. All of the adjustment and accuracy statistics were calculated considering the variable of interest, in this case, macronutrient content. The Meyer correction factor (FM) was used in the logarithm equation to correct logarithmic discrepancy.

After the accuracy of the adjustments and the lack of patterns or tendencies in the residue distribution of the adjusted models were verified, their practical aspects,

Cerne, Lavras, v. 16, n. 3, p. 323-334, jul./set. 2010 
such as facility for measuring the independent variables, were considered.

\section{RESULTS AND DISCUSSION}

After adjustment of several models, the best equations developed for estimating macronutrient contents $(\mathrm{g})$ in the different bracatinga above-ground biomass compartments are presented in Table 2. The Table also shows the selected equations adjustment and accuracy statistics $\left(\mathrm{R}^{2}\right.$ aj. e syx $\left.\%\right)$ and the Meyer correction factor (FM) for the logarithm equations.

Among the biomass compartments, a slight improvement of the adjustment and accuracy statistics is observed for the stem biomass compartments (wood and bark), especially for syx $\%$.

The equations for estimating macronutrients in the wood and bark biomass presented residue distribution values with the lowest amplitude and highest uniformity along the abscissa axis ( $\hat{Y}$ - macronutrient content estimated in grams), as shown in Figures 2 to 4.

In some cases, tendencies were also observed in the residue graphs. In the $\mathrm{N}, \mathrm{P}$ and $\mathrm{K}$ equations, a tendency to underestimation for the lowest concentrations of the nutrients in the leaf biomass was observed. Meanwhile, for the branches $\geq 4 \mathrm{~cm}$, high residues for the lowest $\hat{\mathrm{Y}}$ values were observed, especially in the $\mathrm{N}$ and $\mathrm{Mg}$ equations.

As in this work, most of the studies on adjustments of statistical models for estimating nutrient contents in the biomass of different forest species also found better adjustment results for the nutrients in the stem biomass compartments. (BELLOTE et al., 1983; HOPPE, 2003; LACLAU et al., 2000; RANGER et al., 1995; RANGER \& GELHAYE, 2001). Urbano et al. (2008), working with modeling of bracatinga above-ground biomass in the metropolitan region of Curitiba, also observed a better performance of the statistical models in estimating tree stem biomass, in comparison to the other biomass compartments.

Assessing the quality of the adjustments of the statistical models for each macronutrient, the equations for estimating magnesium concentration presented the worst adjustment and accuracy statistics for most of the biomass compartments. Assessing the nutrient's residue graphs, an uneven distribution with a tendency to overestimation was found, especially in the wood and branches $<4 \mathrm{~cm}$ compartments.

In all the equations for estimating macronutrients in the branches $\geq 4 \mathrm{~cm}$, the independent variable was crown height (hc), while in most of the equations selected for estimating macronutrients in the wood and bark the independent variable was stem height (hf) and its combination with diameter at breast height (d) (Table 2).

In general, the equations resulting from the stepwise procedure presented the best adjustment and accuracy statistical values $\left(\mathrm{R}^{2}\right.$ aj. and syx \%). However, they were not always selected due to their independent variables or to their worse residue distribution.

In some cases, the stepwise procedure selected variables such as age (I) and dominant height $\left(\mathrm{h}_{\text {dom }}\right)$ to compose the statistical model. This demonstrates the strong effect of these variables on macronutrient contents in some compartments of bracatinga above-ground biomass.

According to Hair Junior et al. (2005), sample size, 25 trees in this study, has a direct impact on the adequacy and statistical power of multiple regression. Small samples are adequate for regression analysis that uses few independent variables. Even so, only very strong relations can be detected with some degree of certainty.

Taking this into account, Hair Junior et al. (2005) presented minimum statistically significant $\mathrm{R}^{2}$ values for a determined sample size and number of independent variables in the model. All of selected equations $\mathrm{R}^{2}$ aj. values for estimating macronutrients in bracatinga biomass (Table 2) are higher than the minimum $\mathrm{R}^{2}$ proposed by Hair Junior et al. (2005). Therefore, these selected equations meet the statistical and significance pre-requisites and may be generalized for the bracatinga forests of the metropolitan region of Curitiba.

The $\mathrm{R}^{2}$ aj. results of the equations selected in this work are lower than the results found by Ranger et al. (1995) for Pseudotsuga menziesii in the Beaujolais mountains, France. On the other hand, they are much higher than the results found by Bellote et al. (1983) for Eucalyptus grandis in Mogi-Guaçu, São Paulo state, Brazil.

Laclau et al. (2000) found $\mathrm{R}^{2}$ results similar to those found in this work, in equations for estimating macronutrient contents in the biomass of different Eucalyptus species.

Table 3 shows, apart from the equations developed for estimating macronutrients in each biomass compartment separately, the equations selected for macronutrients in the sum of the biomass compartments and the whole tree above-ground biomass.

The equations for estimating the macronutrients in the sum of the above-ground biomass compartments had a better performance than the equations in Table 2 . 
Table 2 - Best equations developed for estimating macronutrient contents $(\mathrm{g})$ in the different compartments of bracatinga aboveground biomass in the metropolitan region of Curitiba.

Tabela 2 - Melhores equações desenvolvidas para estimativa do conteúdo de macronutrientes ( $g$ ) nos diferentes compartimentos da biomassa aérea de bracatinga na região metropolitana de Curitiba.

\begin{tabular}{|c|c|c|c|c|}
\hline $\begin{array}{l}\text { Biomass } \\
\text { compartment }\end{array}$ & Equation Selected & $\mathrm{R}^{2}$ aj. & syx $\%$ & FM \\
\hline \multirow{5}{*}{ Leaves } & $N=-306.07+104.32 * d-5.5826 * d^{2}-3.6704 * d h+0.27262 * d^{2} h$ & 0.808 & 36.5 & \\
\hline & $P=-15.213+4.8732 * d-0.23264 * d^{2}-0.16644 * d h+0.011261 * d^{2} h$ & 0.792 & 35.7 & \\
\hline & $K=-51.302+16.308 * d-0.78119 * d^{2}-0.55424 * d h+0.037956 * d^{2} h$ & 0.812 & 34.4 & \\
\hline & $C a=-10.194+0.10831 * d^{2}+0.70615 * d c^{2}+3.5994 * h c-0.078304 * d c^{2} h$ & 0.729 & 39.0 & \\
\hline & $M g=-1.2521+0.91232 * h c+0.48093 * d-0.28131 * h d o m$ & 0.748 & 36.4 & \\
\hline \multirow{5}{*}{ Branches $<4 \mathrm{~cm}$} & $N=-226.79+71.672 * d-3.4862 * d^{2}-2.1330 * d h+0.15269 * d^{2} h$ & 0.666 & 34.8 & \\
\hline & $P=-0.061224+0.21702 * d-0.11082 * I$ & 0.630 & 39.1 & \\
\hline & $K=4.2706+0.0015138 * d^{2} h f^{2}-0.0077018 * d c^{2} h f^{2}$ & 0.792 & 39.8 & \\
\hline & $\ln C a=-1.7272+0.66178 * \ln d^{2} h$ & 0.648 & 35.6 & 1.0673 \\
\hline & $M g=14.832+0.00011674 * d^{2} h^{2}-1.9666 * d^{2} h f-0.23887 * I$ & 0.744 & 54.6 & \\
\hline \multirow{5}{*}{ Branches $=4 \mathrm{~cm}$} & $N=-2.9001-0.040484 * d^{2} h+0.00052671 * d^{2} h^{2}+1.8789 * h c+0.16694 * d^{2} h c$ & 0.882 & 39.8 & \\
\hline & $P=-0.24993+0.0080461 * d^{2}-0.26877 * h c+0.078830 * h c^{2}-0.00061591 * d^{2} h c$ & 0.950 & 22.9 & \\
\hline & $K=-24.469+0.022421 * d^{2} h-0.00087805 * d^{2} h^{2}+4.8051 * h c+0.0079117 * d^{2} h c$ & 0.875 & 33.2 & \\
\hline & $\ln C a=-5.7122+2.1517 * \ln d+2.0971 * \ln h c$ & 0.850 & 46.2 & 1.1225 \\
\hline & $M g=4.3919-0.0041289 * d^{2}-2.2983 * h c+0.28973 * h c^{2}+0.0036504 * d^{2} h c$ & 0.799 & 57.5 & \\
\hline \multirow{5}{*}{ Wood } & $\ln N=-2.4286+0.93038 * \ln d^{2} h f$ & 0.893 & 23.7 & 1.0407 \\
\hline & $P=0.48515+0.00074751 * d^{2} h+0.000060701 * d^{2} h f^{2}$ & 0.855 & 26.2 & \\
\hline & $K=257.97+0.15353 * d h f^{2}+9.1004 * I-61.542 * \ln d h f^{2}$ & 0.937 & 26.5 & \\
\hline & $\ln C a=-4.7983+1.1457 * \ln d+2.0897 * \ln h$ & 0.652 & 42.1 & 1.0578 \\
\hline & $\ln M g=-5.3513+1.9047 * \ln d+1.0944 * \ln h f$ & 0.650 & 60.7 & 1.2029 \\
\hline \multirow{5}{*}{ Bark } & $\ln N=-1.9502+0.88279 * \ln d^{2} h f$ & 0.888 & 22.9 & 1.0306 \\
\hline & $\ln P=-5.8307+1.6813 * \ln d+0.96581 * \ln h f$ & 0.880 & 24.0 & 1.0246 \\
\hline & $\ln K=-4.7683+1.6271 * \ln d+1.7372 * \ln h f$ & 0.878 & 30.5 & 1.0442 \\
\hline & $C a=h\left(-3.4604+0.83590 * d-0.010382 * d^{2}\right)$ & 0.882 & 20.7 & \\
\hline & $\ln M g=-4.6921+0.76416 * \ln d^{2} h$ & 0.682 & 38.2 & 1.0843 \\
\hline
\end{tabular}

Where: $\mathrm{d}=$ diameter at breast height $(\mathrm{cm}) ; \mathrm{h}=$ total height $(\mathrm{m}) ; \mathrm{hf}=$ stem height $(\mathrm{m})$; dc = crown diameter $(\mathrm{m})$; hc $=\mathrm{crown}$ height $(\mathrm{m}) ; \mathrm{rc}=$ crown ratio; $\mathrm{h}_{\mathrm{dom}}=$ dominant height $(\mathrm{m}) ; \mathrm{I}=$ age $($ years $) ; \mathrm{ln}=$ natural logarithm. 

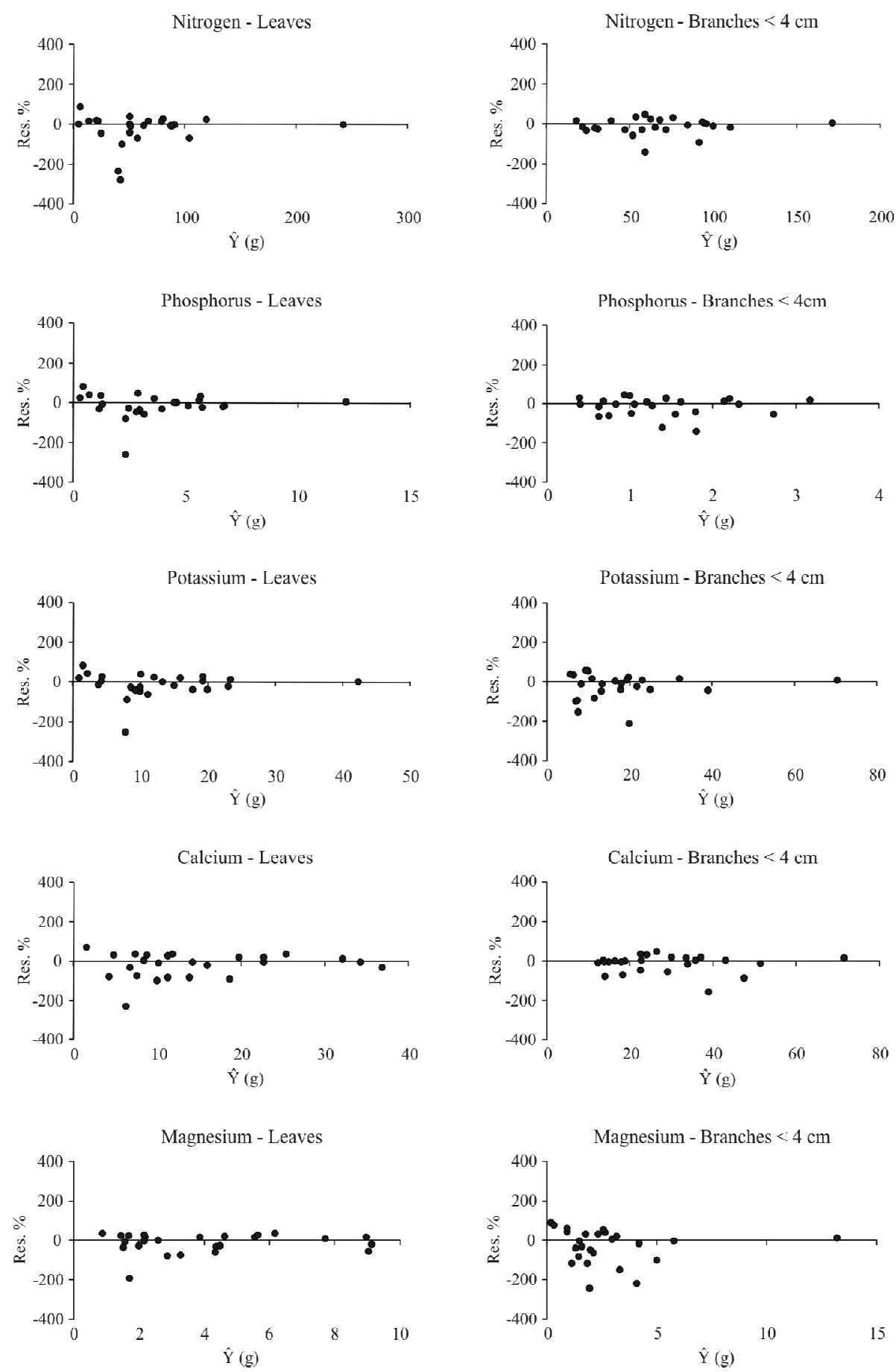

Figure 2 - Residue distribution (\%) of the equations selected for estimating macronutrients (g) in the biomass of bracatinga leaves and branches $<4 \mathrm{~cm}$ in the metropolitan region of Curitiba.

Figura 2 - Distribuição dos resíduos (\%) das equações selecionadas para estimativa do conteúdo de macronutrientes ( $\mathrm{g}$ ) na biomassa de folhas e de galhos menores do que $4 \mathrm{~cm}$ de bracatinga na região metropolitana de Curitiba.

Cerne, Lavras, v. 16, n. 3, p. 323-334, jul./set. 2010 

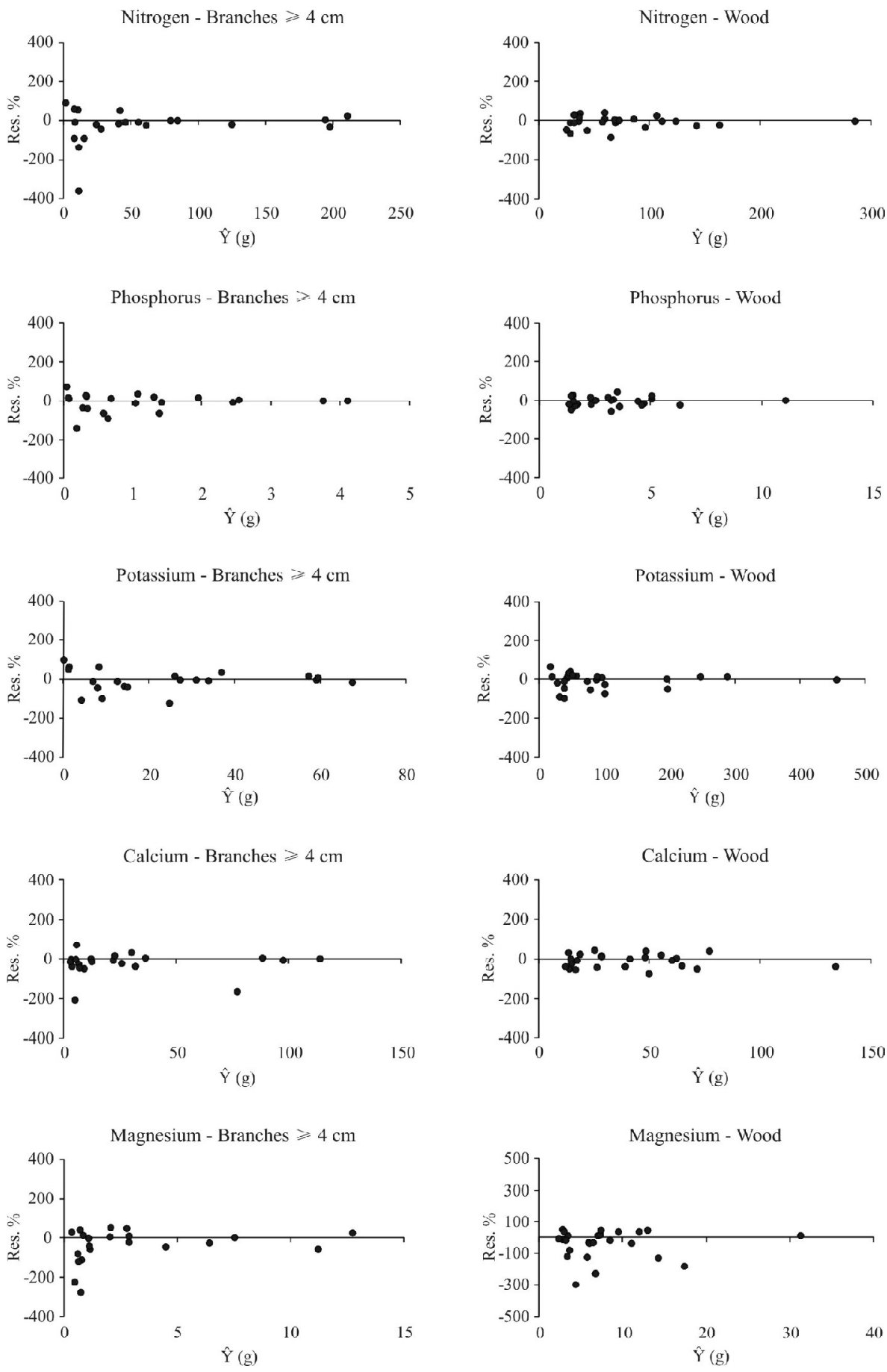

Figure 3 - Residue distribution (\%) of the equations selected for estimating macronutrients $(\mathrm{g})$ in the biomass of bracatinga branches $\geq 4 \mathrm{~cm}$ and wood in the metropolitan region of Curitiba.

Figura 3 - Distribuição dos resíduos (\%) das equações selecionadas para estimativa do conteúdo de macronutrientes ( $\mathrm{g}$ ) na biomassa de galhos maiores ou iguais a $4 \mathrm{~cm}$ e madeira de bracatinga na região metropolitana de Curitiba.

Cerne, Lavras, v. 16, n. 3, p. 323-334, jul./set. 2010 

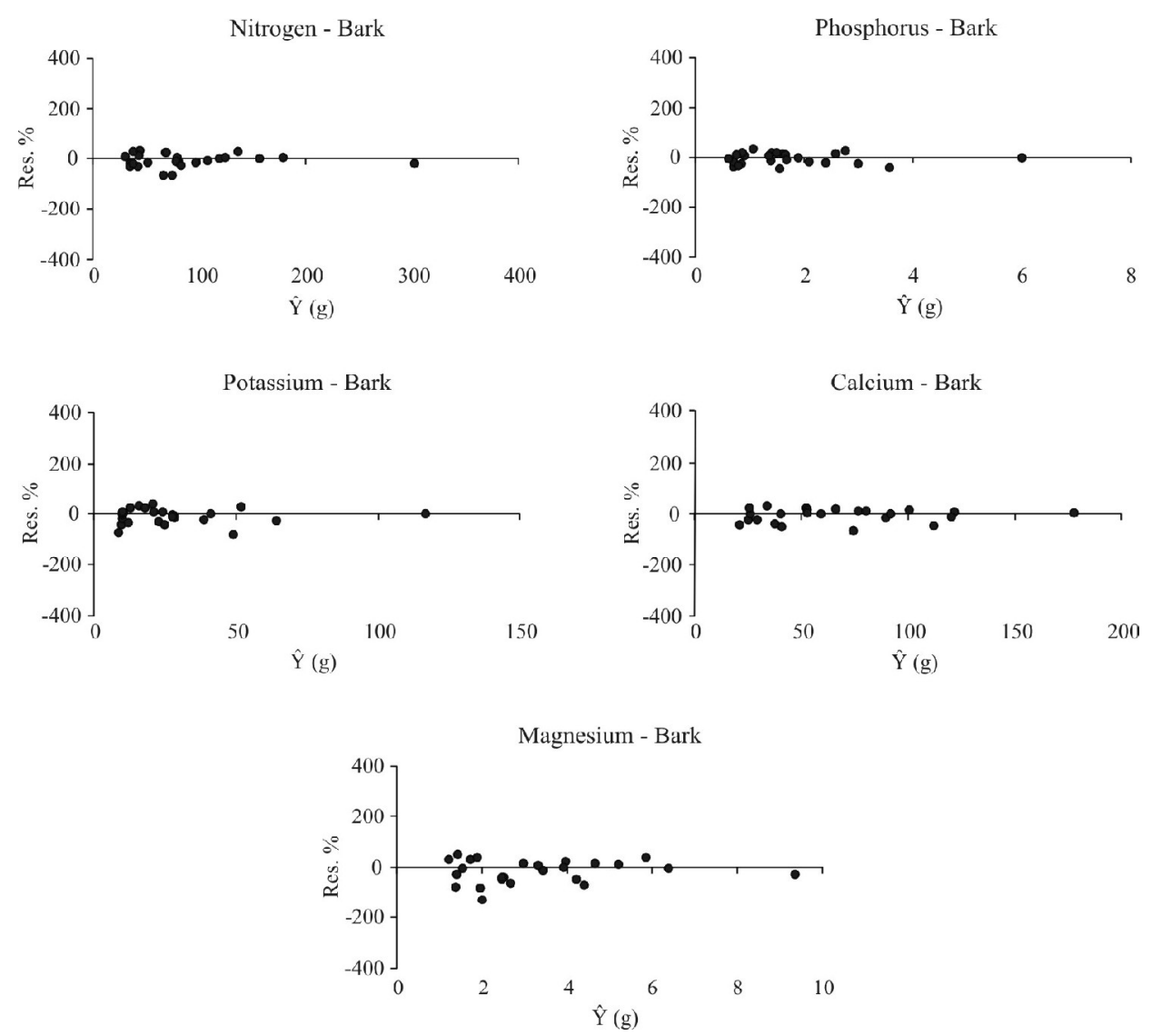

Figure 4 - Residue distribution $(\%)$ of the equations selected for estimating macronutrients $(\mathrm{g})$ in the biomass of bracatinga bark in the metropolitan region of Curitiba.

Figura 4 - Distribuição dos resíduos (\%) das equações selecionadas para estimativa do conteúdo de macronutrientes (g) na biomassa de casca de bracatinga na região metropolitana de Curitiba.

The enhanced performance of the equations in Table 3, in relation to the previous one, is confirmed by analysis of the residue graphs (Figures 5 and 6). These graphs show residue distributions with lower amplitude values and higher uniformity along the abscissa axis $(\hat{Y}-$ macronutrient content estimated in grams), in relation to Figures 2, 3 and 4. It is important to highlight that, as they have lower residue values, the residue graphs of Figures 5 and 6 are presented on a different scale to Figures 2 to 4 . But even so, the improvement in residue distribution is still evident.

Therefore, as can be seen from the equations in Table 2, the models presented the worst adjustment and accuracy statistical values in the estimations of macronutrient concentrations in the crown compartments. On the other hand, in the estimations of macronutrients in the firewood and the whole bracatinga above-ground biomass, the models presented better adjustment and accuracy statistical values.

However, assessing the residue graphs, there were no great improvements in the residue distribution of the firewood and the whole above-ground biomass equations selected, in relation to the residue distribution of the crown equations (leaves + branches $<4 \mathrm{~cm}$ ).

As the equations in Table 2, the equations for estimating magnesium content presented the worst adjustment and accuracy statistics, when compared to the equations of the remaining nutrients.

Contrary to what occurred with the bracatinga above-ground biomass compartments assessed separately, variables such as age (I) and dominant height $\left(\mathrm{h}_{\mathrm{dom}}\right)$ did not provide relevant gains in the equations for estimating macronutrients resulting from the stepwise procedure. 
Table 3 - Best equations developed for estimating macronutrients $(\mathrm{g})$ in the leaves + branches $<4 \mathrm{~cm}$ and firewood compartments and in the whole bracatinga above-ground biomass in the metropolitan region of Curitiba.

Tabela 3 - Melhores equações desenvolvidas para estimativas do conteúdo de macronutrientes ( $g$ ) para os compartimentos folhas + galhos $<4 \mathrm{~cm}$, lenha e para toda a biomassa aérea da bracatinga na região metropolitana de Curitiba.

\begin{tabular}{|c|c|c|c|c|}
\hline $\begin{array}{l}\text { Biomass } \\
\text { compartment }\end{array}$ & Equation Selected & $\mathrm{R}^{2}$ aj. & syx $\%$ & FM \\
\hline \multirow{5}{*}{$\begin{array}{l}\text { Leaves }+ \\
\text { Branches }<4 \mathrm{~cm}\end{array}$} & $N=-532.86+175.99 * d-9.0688 * d^{2}-5.8034 * d h+0.42531 * d^{2} h$ & 0.855 & 25.6 & \multirow{4}{*}{1.0697} \\
\hline & $\ln P=5.2674-0.44125 * \ln d-29.611 * d^{-1}$ & 0.690 & 40.0 & \\
\hline & $K=-86.831+30.198 * d-1.7688 * d^{2}-1.0091 * d h+0.089397 * d^{2} h$ & 0.824 & 33.1 & \\
\hline & $C a=-46.154+9.2987 * d-0.11376 * d^{2}$ & 0.700 & 32.6 & \\
\hline & $\ln M g=-4.2174+0.79558 * \ln d^{2} h$ & 0.665 & 43.6 & 1.0712 \\
\hline \multirow{5}{*}{ Firewood } & $N=45.298+2.8787 * d^{2}-0.26968 * d^{2} h+0.31247 * d h^{2}-2.1546 * h^{2}$ & 0.943 & 17.3 & \\
\hline & $P=-0.30026+0.0025022 * d h^{2}$ & 0.896 & 22.1 & \\
\hline & $K=-158.94+0.0059665 * d^{2} h f^{2}+13.574 * I+0.43617 * h^{2}$ & 0.928 & 25.4 & \\
\hline & $C a=h\left(-15.816+2.9942 * d-0.066973 * d^{2}\right)$ & 0.938 & 16.0 & \\
\hline & $M g=\frac{d^{2} h}{\left(199.19-0.73669^{*} h\right)}$ & 0.681 & 48.8 & \\
\hline \multirow{5}{*}{ Total } & $N=-842.38+241.42 * d-11.361 * d^{2}-6.6780 * d h+0.54259 * d^{2} h$ & 0.960 & 13.6 & \\
\hline & $P=-27.081+8.0756 * d-0.42159 * d^{2}-0.21847 * d h+0.019757 * d^{2} h$ & 0.881 & 23.2 & \\
\hline & $K=-446.63+0.0073548 * d^{2} h f^{2}+11.935 * I+52.526 * \ln d h^{2}$ & 0.925 & 24.9 & \\
\hline & $C a=h\left(-18.743+3.6858 * d-0.081229 * d^{2}\right)$ & 0.925 & 16.8 & \\
\hline & $M g=67.465+0.012953 * d h^{2}-11.563 * \ln d h f^{2}$ & 0.849 & 31.1 & \\
\hline
\end{tabular}

Where: $\mathrm{d}=$ diameter at breast height $(\mathrm{cm}) ; \mathrm{h}=$ total height $(\mathrm{m})$; $\mathrm{hf}=$ height of the stem $(\mathrm{m})$; dc $=$ diameter of the canopy $(\mathrm{m})$; hc $=$ height of the canopy $(\mathrm{m}) ; \mathrm{rc}=$ ratio of the canopy; $\mathrm{h}_{\mathrm{dom}}=$ predominant height $(\mathrm{m}) ; \mathrm{I}=$ age (years); $\ln =$ natural logarithm. 

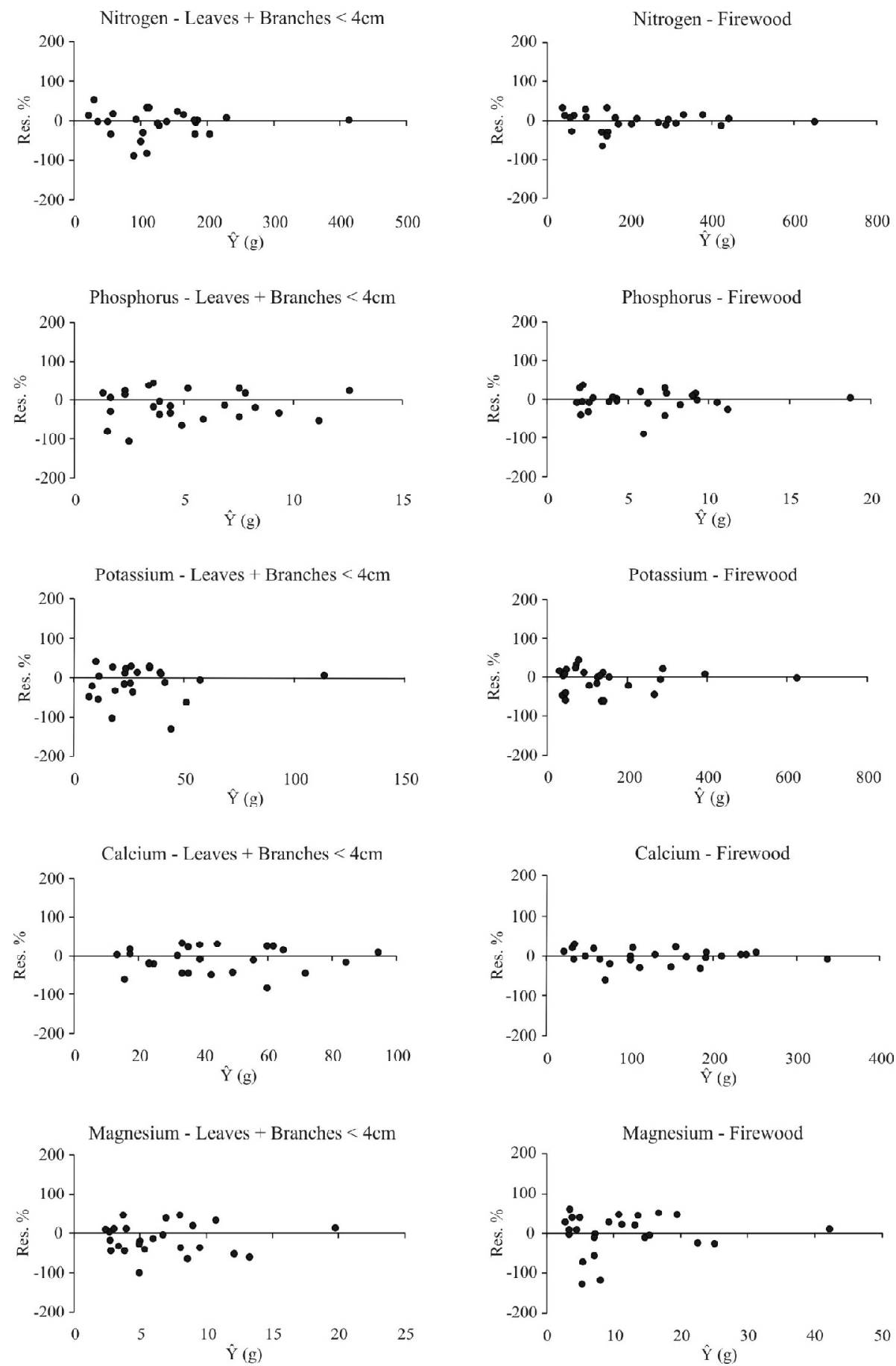

Figure 5 - Residue distribution (\%) of the equations selected for estimating macronutrients $(\mathrm{g})$ in the biomass of bracatinga leaves + branches $<4 \mathrm{~cm}$ and firewood in the metropolitan region of Curitiba.

Figura 5 - Distribuição dos resíduos (\%) das equações selecionadas para estimativa do conteúdo de macronutrientes ( $\mathrm{g}$ ) na biomassa de folhas + galhos menores do que $4 \mathrm{~cm}$ e lenha de bracatinga na região metropolitana de Curitiba.

Cerne, Lavras, v. 16, n. 3, p. 323-334, jul./set. 2010 

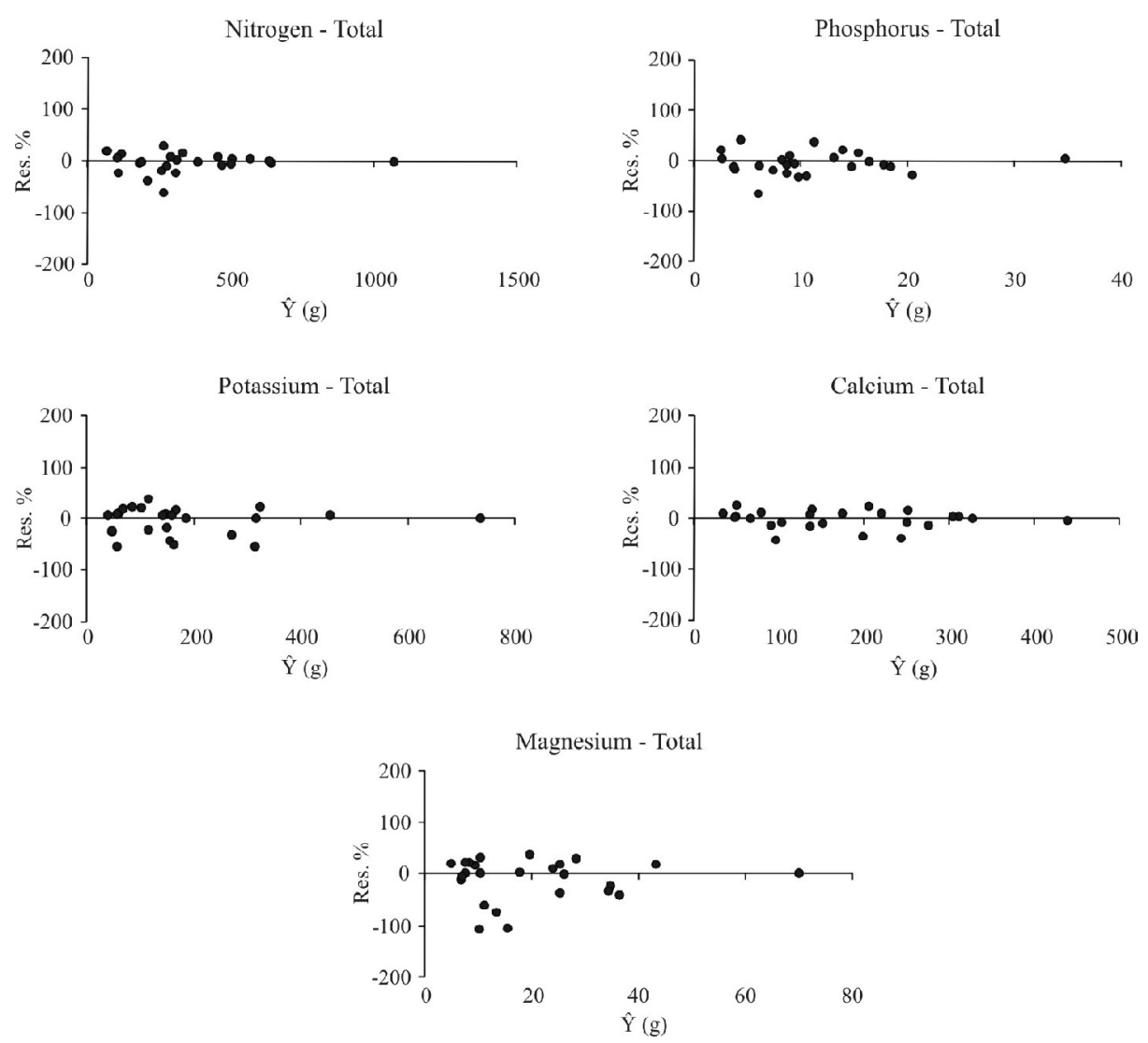

Figure 6 - Residue distribution (\%) of the equations selected for estimating macronutrients (g) of the whole bracatinga aboveground biomass in the metropolitan region of Curitiba.

Figura 6 - Distribuição dos resíduos (\%) das equações selecionadas para estimativa do conteúdo de macronutrientes ( $\mathrm{g}$ ) para toda biomassa aérea de bracatinga na região metropolitana de Curitiba.

\section{CONCLUSIONS}

The relations between dendrometric variables and the macronutrient concentrations were satisfactory and provided acceptable equations. However, the equations for estimating magnesium content should be used cautiously.

In general, the quality of the adjustments improves significantly in the equations that estimate macronutrient contents in the sum of the biomass compartments. Therefore, these equations are preferable.

The equations for estimating macronutrients in the tree stem compartments presented a better performance than the crown equations.

An improvement was observed in the quality of the adjustments of the nutrient equations when canopy and stem dimensions were included as independent variables, as well as age (I) and dominant height $\left(\mathrm{h}_{\mathrm{dom}}\right)$, in some cases.

Better adjustments of the nutrient concentration equations might have been found if the data used were taken from a more homogeneous population, for example, one with a single location and age class.

\section{BIBLIOGRAPHICAL REFERENCES}

BAGGIO, A. J.; CARPANEZZI, A. A. Exportação de nutrientes na exploração de bracatingais. Boletim de Pesquisa Florestal, Colombo, n. 34, p. 3-15, 1997.

BELLOTE, A. F. J.; SARRUGE, J. R.; HAAG, H. P.; OLIVEIRA, G. D. de. Absorção de macronutrientes e micronutrientes pelo Eucalyptus grandis (Hill, ex-Maiden) em função da idade. Silvicultura, São Paulo, n. 32, p. 633-643, 1983.

Cerne, Lavras, v. 16, n. 3, p. 323-334, jul./set. 2010 
HAIR JUNIOR, J. F.; ANDERSON, R. E.; TATHAM, R. L.; BLACK, W. C. Análise multivariada de dados. 5. ed. Porto Alegre: Bookman, 2005. 593 p.

HOPPE, J. M. Biomassa e nutrientes em Platanus $x$ acerifolia (Aiton) Willd. estabelecido no município de Dom Feliciano RS. 2003. 143 p. Tese (Doutorado em Engenharia Florestal) Universidade Federal de Santa Maria, Santa Maria, 2003.

KIMMINS, J. P. Evaluation of the consequences for future tree productivity of the loss of nutriens in whole-tree harvesting. Forest Ecology and Management, Amsterdam, v. 1, n. 2, p. 169-183, 1977.

LACLAU, J. P.; BOUILLET, J. P.; RANGER, J. Dynamics of biomass and nutrient accumulation in a clonal plantation of Eucalyptus in Congo. Forest Ecology and Management, Amsterdam, v. 128, n. 3, p. 181-196, 2000.

LEAR, D. H. van; WAIDE, J. B.; TEUKE, M. J. Biomass and nutrient content of a 41-year-old Loblolly pine (Pinus taeda L.) plantation on a poor site in South Carolina. Forest Science, Bethesda, v. 30, n. 2, p. 395-404, 1984.

MAACK, R. Geografia física do estado do Paraná. 3. ed. Curitiba: Imprensa Oficial do Paraná, 2002. 440 p.

MORO, L.; REISSMANN, C. B.; SILVA, H. D. da; FERREIRA, C. A.; LAVORANTI, O. J. Modelos matemáticos para estimativa de exportação de nutrientes em povoamentos de Pinus taeda L. Floresta, Curitiba, v. 37, n. 2, p. 223-230, 2007.
RANGER, J.; GELHAYE, D. Belowground biomass and nutrient content in a 47-year-old Douglas-fir plantation. Annals of Forest Science, Paris, v. 58, n. 4, p. 423-430, 2001.

RANGER, J.; MARQUES, R.; COLIN-BELGRAND, M.; FLAMMANG, N.; GELHAYE, D. The dynamics of biomass and nutrient accumulation in a Douglas-fir (Pseudotsuga menziesii Franco) stand studied using a chronosequence approach. Forest Ecology and Management, Amsterdam, v. 72, n. 2, p. 167-183, 1995.

SOMARRIBA, E.; KASS, D. Estimates of above-ground biomass and nutrient accumulation in Mimosa scabrella fallows in southern Brazil. Agroforestry Systems, Amsterdam, v. 51, n. 2 , p. 77-84, 2001.

URBANO, E.; MACHADO, S. A.; FIGEUIREDO FILHO, A.; KOEHLER, H. S. Modelagem da biomassa aérea em bracatingais nativos da região metropolitana de Curitiba. Floresta, Curitiba, v. 38, n. 2, p. 361-372, 2008.

YOUNG, H. E. Challenge of complete tree utilization. Forest Products Journal, Madison, v. 18, n. 4, p. 83-85, 1968.

ZILLER, S. R.; RIBASKI, J.; NEVES, E. J. M.; WISNIEWSKI, C.; CURCIO, G. R.; RACHWAL, M. F. G.; MARTINS, E. G.; MARTINEZ, C. M.; SOUZA, S. L. de; PANZERI, C. G.; MASCHIO, W. Relação entre serapilheira acumulada, características fitossociológicas e pedológicas em quatro capoeiras de bracatinga (Mimosa scabrella Bentham) na região metropolitana de Curitiba - PR. Arquivos de Biologia e Tecnologia, Curitiba, v. 39, n. 4, p. 911-921, 1996. 